\title{
The Netherlands Standing Government Committee on Private International Law
}

\author{
Paul Vlas
}

\section{TOBIAS ASSER'S DREAM}

The history of the Netherlands Standing Government Committee on Private International Law ('Standing Committee') is closely connected with a Dutch scholar and his work: Tobias Michael Carel Asser (1838-1913). ${ }^{1}$ Asser was not only one of the founding fathers of the Hague Conference on Private International Law $(\mathrm{HCCH})$ (as it is now called) and its first President, but he also took the initiative of establishing the Standing Committee. It is well known that Asser had connections within the Dutch government, especially with the Dutch Minister of Foreign Affairs. In 1893 Asser used his contacts to persuade the Dutch government to convene an international conference on the regulation of a number of questions of private international law. On 12 September 1893, the opening session of this conference took place in the Salle de Trèves located at the Binnenhof, the historic government buildings in the Hague. This occasion marked the beginning of the Hague Conference (or the 'Conference'). When Asser was elected as President of the Conference, he thanked all participants for their confidence in him and said it was one of the dreams of his youth which had just started on the road to realisation. ${ }^{2}$

After the second Hague Conference in 1894, Asser was convinced that a Standing Committee was needed. In his view, this Committee should take the necessary steps towards the advancement of the codification of private international law. By using the notion 'codification' Asser did not mean a national codification of private international law, but its promotion by treaties. In Asser's view the Dutch government had a special duty and task to promote the conclusion of treaties in this respect, due to the government's involvement in convening the (first) Conference in 1893. A Standing Committee could prepare the necessary measures for the international codification. ${ }^{3}$

1 See also Paul Vlas, 'Speech held at the Commemorative Ceremony to mark the 125 th Anniversary of the Hague Conference' (12 September 2018) in Annual Report of the Hague Conference (2018), 15-16.

2 Proceedings (Actes) of the opening Session of the Hague Conference, 26.

3 The history of the Standing Government Committee is sketched in a text written by G.J.W. Steenhoff, Honderd jaar Staatscommissie voor het Internationaal Privaatrecht 100 Years Standing Government Committee on Private International Law] (Ministry of Justice, The Hague). This booklet was printed in a private edition of 300 copies and distributed to the Members of the Standing Government Committee at the celebration of the Committee's Centenary on 21 February 1997. Steenhoff also wrote a booklet on the history of the HCCH offered by the Dutch Ministry of Justice on the occasion of the Centenary of the HCCH in 1993: G.J.W. Steenhoff, Avec patience et courage (Dutch Ministry of Justice, 1993). 


\section{THE ESTABLISHMENT OF THE STANDING COMMITTEE}

In February 1897, the Dutch Ministers of Foreign Affairs and of Justice presented to Queen-Regent Emma (1890-98) a draft Royal Decree establishing the Standing Committee. In the explanatory memorandum, the ministers expressed that the Dutch government accepted the responsibility for taking the leadership in this respect and underlined the government's duty to promote the codification programme as proposed during the 1893 and 1894 Conferences.

On 20 February 1897, Queen-Regent Emma signed the Royal Decree establishing the Standing Committee. ${ }^{4}$ The decree mentioned the Committee's purpose: the preparation of the necessary arrangements for the advancement of the codification of private international law. It was no surprise that Tobias Asser became the Committee's first President. The members of the Standing Committee were recruited from Dutch Parliament, the judiciary (especially the Dutch Supreme Court (Hoge Raad)), the Ministries of Foreign Affairs and of Justice and, last but not least, the Dutch Council of State (Raad van State). The academic profession was not forgotten: apart from being a member of the Council of State, Asser had been professor of law at the Athenaeum Illustre (what is now the University of Amsterdam). ${ }^{5}$

The first meeting of the Standing Committee took place on 2 March 1897 in the Salle de Trèves, where - as mentioned above - the first Conference was held in 1893. After ceremonial speeches, Asser reported on the 1894 Convention on Civil Procedure, the first result of the Conference. The Committee prepared the next Conference, which was held in 1900. The Standing Committee served as the steering body of the Conference, which was undoubtedly owed to Asser's commitment to the international codification of private international law. Asser remained the Committee's President until his death in 1913. He was succeeded by Theodorus Heemskerk (1852-1932), who was also a member of the Dutch Council of State. Heemskerk stayed President of the Standing Committee until 1918, when he became Minister of Justice. The next President was Daniël Josephus Jitta (1854-1925), a well-known scholar and professor of private international law and commercial law at the University of Amsterdam (the chair he took over from Asser in 1893). Jitta stayed President until his resignation in 1924. He was succeeded by Bernard C.J. Loder (1849-1935). Together with Asser, Loder had been one of the founding fathers of the Comité de Maritime International. In 1921, Loder became a member of the Permanent Court of Arbitration in the Hague. In 1922, he was elected as the Court's first President. Until his death in 1935 Loder chaired the Standing Committee.

After the fourth Hague Conference in 1904, international political developments made it impossible to convene a new one. The fifth and sixth 'sessions' of the Hague Conference were held in 1925 and 1928. After these sessions the international political situation deteriorated, and the spirit of international co-operation disappeared. The work of the Hague Conference came to a standstill. After Loder's death in 1935, Carel D. Asser Jr. (Tobias Asser's son) became Chair of the Standing Committee. Carel Asser was a lawyer at the Amsterdam bar and deputy judge in the District Court of Amsterdam. In 1939, he was succeeded by Jan Kosters (1874-1951), professor of civil and private international law at Groningen University and at the end of his career as a member of the Dutch Supreme Court.

\footnotetext{
4 Staatscourant (Netherlands Offical Newspaper, 1897), nr. 46.

5 See Tobias Asser, 'Inaugural Address on Commercial Law and Commerce' (Amsterdam, 1862) in Ernst Hirsch Ballin (ed), A Mission of His Time (Asser Press, 2012).
} 


\section{REVIVAL AFTER THE SECOND WORLD WAR}

After the horrors of the Second World War, mankind longed for new initiatives and international co-operation on various aspects of international trade and commerce. New international organisations were established (such as the UN, the Organisation for Economic Co-operation and Development (OECD) and the International Bank for Reconstruction and Development). The work on the international codification of private international law was also to be resumed. Hence, a revival of the Hague Conference was necessary. The Standing Committee had its first meeting on 14 December 1946 under the chairmanship of Jan Kosters. The Committee decided to start consultations for the preparation of the next session of the Conference. In view of the work to be expected, it was deemed necessary to increase the number of members of the Committee. Until 1947, it had been a small committee of six eminent scholars (all men). In 1947, the Committee was enlarged with seven new members, among whom was the first female member, Mrs. L.C. Schönfeld-Polano (counsellor at the Ministry of Justice). A young public servant at the Ministry of Foreign Affairs, Matthijs van Hoogstraten (1913-80), became Secretary of the Standing Committee and was charged with the preparatory work for the revival of the Conference. In 1947, Kosters resigned as Chair of the Standing Committee for health reasons and the question of his succession thus arose. The preferred candidate was Eduard M. Meijers (1880-1954), a well-known professor of law at Leiden University and since 1935 a member of the Committee. However, he refused the chairmanship because of his work on the new codification of the Dutch Civil Code. It was not until 1952, when Johannes Offerhaus (1892-1966) was appointed as Chair. Offerhaus was professor of civil and commercial law and private international law at the University of Amsterdam, and one of Tobias Asser's successors at the University. Offerhaus worked together with his Swiss colleague, Professor Max Gutzwiller and his French counterpart, Professor Julliot de la Morandière, on the revival of the Conference. However, Matthijs van Hoogstraten was the moving spirit behind the work. The efforts for the revival would have most likely failed without his enthusiasm, perseverance and diplomatic skills.

Finally, the seventh session of the Conference took place in 1951. Two important topics were discussed: corporations and the international sale of goods. Upon the proposal of the Standing Committee, Offerhaus was elected as President of the Conference and van Hoogstraten as Secretary-General. The latter provided the Hague Conference with a draft statute, which was accepted. In the following years this Statute was ratified by several States. ${ }^{6}$ It came into force on 15 July 1955. Van Hoogstraten became the first Secretary-General of the Conference, which he remained until his death in 1980 .

\section{THE ROLE OF THE STANDING COMMITTEE IN THE HCCH STATUTE}

The HCCH Statute acknowledged the important role played by the Standing Committee, and especially by its Chairs, in the revival and refunctioning of the Hague Conference. The

${ }^{6}$ The first States that ratified were Austria, Belgium, Denmark, Netherlands, Norway, Spain, Sweden and the United Kingdom. 
$\mathrm{HCCH}$ Statute mentioned two organs of the Conference: the Standing Committee as the steering body and the Permanent Bureau (PB), directed by the Standing Committee (Article 3). According to the $\mathrm{HCCH}$ Statute, the Standing Committee examined all proposals for the agenda of the Conference, and fixed the dates of its diplomatic sessions, after consultation with the Member States. Article 4 stated that The Hague was the Conference's seat and that the Secretary-General and the Secretaries were appointed by the Dutch government upon the presentation of the Standing Committee. The costs of the ordinary and extraordinary sessions were to be paid by the Dutch government (Article 10).

The Standing Committee had to decide on new proposals for 'unification' to be placed on the agenda of the Conference (the word 'codification' was no longer used). The Committee also played an important role in daily matters. There was frequent contact between Offerhaus and the Secretary-General, van Hoogstraten. Offerhaus resigned as Chair of the Standing Committee in 1965 and was succeeded by Leo I. de Winter (1911-72), who was appointed as professor of private international law at the University of Amsterdam in 1962. De Winter started his chairmanship in a new era: many new international organisations were engaged in efforts for the unification of the law (for example the European Economic Community (EEC) and United Nations Commission on International Trade Law (UNCITRAL), and the International Commission on Civil Status). De Winter was not apprehensive for competition, because the Conference had prestige, experience and an excellent PB. The quality of the delegates to the Conference also contributed to its success. ${ }^{7}$ De Winter presided over three sessions of the Conference: in 1966 (an extraordinary session) and in 1968 and 1972. He died unexpectedly just a few days after the 12th session in 1972 .

De Winter was succeeded by Jan C. Schultsz (1927-94), lawyer and professor of law at Rotterdam Law School. Schultsz had become a member of the Standing Committee in 1963. Schultsz was one of Offerhaus' pupils, wrote his PhD-thesis under Offerhaus' supervision ${ }^{8}$ and was Offerhaus' personal secretary during the seventh session of the Conference in 1951. Schultsz presided over five sessions of the Conference: from the 13th session in 1976 up to and including the 17 th session in 1993.

During Schultsz' chairmanship of the Standing Committee, the role of the Committee as steering body of the Conference changed due to new perceptions among Member States. The fact that a national organ gave direction to an international organisation was regarded somewhat archaic, although it could be explained from an historical point of view. Gradually, the steering role of the Standing Committee shifted to the Commission on General Affairs of the Conference. However, the Standing Committee and its Chair stayed involved in fixing the dates of the diplomatic sessions and in the appointment of the secretaries of the PB according to the provisions of the HCCH Statute.

In 1978, J.H.A. (Hans) van Loon (1948), a lawyer from the Hague Bar, was appointed as one of the Secretaries of the Permanent Bureau. He also became Secretary of the Standing

\footnotetext{
7 See L.I. de Winter, 'Les 75 ans d'existence de la Commission d'Etat neérlandaise pour le droit international privé' 75 Years of Existence of the Dutch Standing Government Committee on Private International Law] (1971) Nederlands Tijdschrift voor Internationaal Recht, 261-74, reprinted in I. Kisch et al (eds), Naar een Sociaal I.P.R., Een keus uit het werk van L.I. de Winter (Kluwer, 1979) 64, 76.

8 J.C. Schultsz, Eigendomsverkrijging bij koop van roerende goederen in het Westeuropees Internationaal Privaatrecht (Martinus Nijhoff, 1955).
} 
Committee. In 1978, Georges A.L. Droz (1931-2004), who joined the PB in 1957, succeeded van Hoogstraten as Secretary-General. Droz remained in office until his retirement in 1996. Hans van Loon became his successor and resigned as Secretary of the Standing Committee.

\section{CODIFICATION OF DUTCH PRIVATE INTERNATIONAL LAW}

Under the Presidency of Jan Schultsz, the national task of the Standing Committee became more important. The Dutch government asked the Committee's advice over a great deal of matters concerning private international law. ${ }^{9}$ Not only questions relating to the ratification of Hague Conventions were discussed, but also the question whether the rules of Dutch private international law should be codified. The ultimate aim was a national codification, just as Switzerland had done in 1987. The Dutch Ministry of Justice initiated a codification step by step: separate bills on several matters of private international law were drafted and the Standing Committee was asked to give advice. Meetings of the Standing Committee, mostly held on Saturday mornings, started with the international task (questions relating to the $\mathrm{HCCH}$ ) and continued with discussions on matters relating to the national task.

The sudden death of Jan Schultsz in 1994 shocked the members of the Standing Committee. Some months later Antoon (Teun) V.M. Struycken (1936) was appointed as Chair. Teun Struycken was professor of private international law at the Catholic University of Nijmegen and since 1975 member of the Standing Committee. He was an active participant in the work of the Standing Committee and had international experience. During his presidency (1995-2011) the codification of Dutch private international law was accomplished. In the end, 16 separate Acts on private international law were consolidated in Book 10 of the Dutch Civil Code, which came into force on 1 January $2012 .^{10}$

\section{A NEW ACT REGARDING THE STANDING COMMITTEE AND A NEW STATUTE}

In 1996, the Dutch Parliament accepted the Act on general rules for national advisory bodies. ${ }^{11}$ This Act provided for a framework (about instituting advisory bodies, their structure and organisation). The Standing Committee, however, was (and still is) mentioned in the HCCH Statute and is of another nature than national advisory organs. Hence, a separate Act dealing with the Standing Committee was necessary. On 14 February 1998, the Dutch Parliament accepted the Act 'concerning the composition and activities of the Standing Government Committee for the preparation of the measures to be taken for the advancement of the codification of private international law'. ${ }^{12}$ The Act had retrospective effect as from 1 January 1997. Article 1 states explicitly that the Standing Committee was established by Royal Decree of 20

\footnotetext{
9 See for a collection of the Committee's advices: E.N. Frohn and E. Hennis (eds), Staatscommissie IPR. Geselecteerde Adviezen - Naar een afgewogen IPR (T.M.C. Asser Instituut, 1995).

10 Act of 18 May 2011, 'Staatsblad' (2011) Official Journal 2011/272. See a.o. A.V.M. Struycken, 'The Codification of Dutch Private International Law' (2014) 78 RabelsZ 592, 614.

11 Act of 3 July 1996, 'Staatsblad' (1996) Official Journal, 378.

12 'Staatsblad' (1998) Official Journal, 208.
} 
February 1897. The minimum number of members is 10 with a maximum of 20 . The term of appointment is four years, to be renewed without limitation (this was done because experts in private international law are scarce and their expertise is highly appreciated). According to Article 2, the Standing Committee is entrusted with the tasks laid down in the HCCH Statute. The Committee can also advise both chambers of the Dutch Parliament regarding legislative matters of private international law (Article 2, paragraph 2). The Act on the Standing Committee is a lex specialis in relation to the abovementioned 1996 Act.

The advisory task of the Dutch Standing Committee radically changed when the European Community (now EU) got regulatory power in the field of private international law. Regulations were made, which are binding for the EU Member States. The Standing Committee advised employees of the Dutch Ministry of Justice in view of the negotiations in Brussels, but initiatives for new national legislation in the field of private international law became rare for many matters were already dealt with in EU regulations. EU Member States could no longer take a view in the $\mathrm{HCCH}$, because most matters - e.g. jurisdiction and recognition and enforcement of judgments - were the subject of EU regulations and therefore no longer the domain of the national legislator. Amendments of the $\mathrm{HCCH}$ Statute were necessary. The Statute sought to give the EU as a Regional Economic Integration Organisation the opportunity to accede to the Hague Conventions and to take part in the negotiations. It was also time to formalise the changed role of the Standing Committee.

During the 20th session of the Conference, under Struycken's Chairmanship, amendments to the $\mathrm{HCCH}$ Statute were adopted on 30 June 2005. The new (amended) HCCH Statute entered into force on 1 January 2007. In line with accepted practice, Article 4 of the HCCH Statute provides that CGAP (what used to be the 'Commission on General Affairs') has charge over the operation of the HCCH. It is no longer the Standing Committee that directs the activities of the PB, but CGAP. It is CGAP that shall examine the proposals to be placed on the agenda of the HCCH. However, the role of the Standing Committee is still acknowledged: the Standing Committee shall, after consultation of the Members, determine the date of the Diplomatic Sessions, address itself to the Dutch government for the convocation of the Members and may be consulted by the Council on any other matter relevant to the HCCH. The Chair of the Standing Committee presides over the sessions of the $\mathrm{HCCH}$ (Article 4, paragraphs 4-8). The provision that the Secretary-General and the Secretaries of the Permanent Bureau shall be appointed by the Dutch government upon the presentation of the Standing Committee remained in the HCCH Statute (Article 5, paragraph 1). The expenses resulting from the ordinary and extraordinary sessions remained to be borne by the Dutch government (Article 11). In 2005, there was no discussion on these remaining tasks of the Dutch Standing Committee.

\section{THE PRESENT ROLE OF THE STANDING COMMITTEE IN THE HAGUE CONFERENCE}

In 2011, Teun Struycken resigned as President of the Standing Committee. He was succeeded by the author of this contribution. The Dutch Ministry of Justice still asks the Standing Committee for advice about many initiatives for new EU legislation regarding private inter- 
national law. In 2019, the 22nd session of the HCCH took place. ${ }^{13}$ Since the 21 st session in 2007 (presided by Teun Struycken), there had been no diplomatic session. However, between 2007 and 2019 many meetings of Special Commissions took place about a variety of subjects relating to existing Hague Conventions. During these meetings, the Chair of the Standing Committee always represented the Netherlands. The Standing Committee, and especially its Chair, is the intermediary between the $\mathrm{HCCH}$ and the host state. The tasks of the Standing Committee according to the HCCH Statute are in fact exercised by the Committee's President. She or he informs the Committee of their activities and is empowered to carry out the tasks according to the HCCH Statute. In 2013, Hans van Loon retired as Secretary-General of the Organisation. CGAP appointed a selection committee for the appointment of his successor. The Chair of the Standing Committee became a member of the selection committee and facilitated the proceedings. The outcome of the selection was the appointment of the present Secretary-General, Christophe Bernasconi (1964). According to Article 5 of the HCCH Statute, the Standing Committee presents the selected candidate for appointment to the Dutch government. The appointment takes place by decree of the Minister of Foreign Affairs of the Netherlands. In view of this procedure, it is very useful that the Chair of the Standing Committee is involved in the selection procedure. Just as his predecessors, the present Chair sees it as his task to ensure a smooth procedure and thus to fulfil the wishes of the Member States of the HCCH.

Nowadays the Standing Committee has 14 members, who come from academia, the legal profession and the judiciary. The members are appointed by Royal Decree for a term of four years (renewable). The meetings of the Committee's plenary take place on average three times a year. For large complicated legislative projects, the Committee may designate a subcommittee that prepares a piece of draft advice for discussion in the plenary. This was done in 2018 in order to prepare the Committee's advice about matters relating to parentage and surrogacy in Dutch private international law. In 2019, the Committee advised about the issue of recognition and enforcement of civil judgments emanating from States with which no treaty arrangements exist.

\section{CONCLUDING REMARKS}

As the discussion above has shown, the Netherlands is very closely linked to the HCCH by virtue of how that organisation has evolved. It is the oldest international organisation based in The Hague. Since the days of Tobias Asser, the successive Chairs of the Standing Committee have always had a historical link with the $\mathrm{HCCH}$. They all believed strongly that an organisation such as the $\mathrm{HCCH}$ was necessary for the unification of private international law. The role of the Netherlands and the Dutch Standing Committee has of course changed over the years. While in its first 80 years of existence, the Standing Committee played a substantive role, nowadays, it performs a more modest, facilitating function. What has not changed is the

13 On the 22nd Session, which adopted the 2019 Judgments Convention, see Ronald A. Brand, 'The 2005 Choice of Court Convention - the triumph of party autonomy', Chapter 22 in this volume; Richard Garnett, 'The Judgments Project: fulfilling Asser's dream of free-flowing judgments', Chapter 23 in this volume. 
10 The Elgar companion to the $\mathrm{HCCH}$

Standing Committee's firm commitment to the unification of private international law for the benefit of all of the world's citizens. 